\title{
Exploring the Recent Advances in Stem Cell Research
}

\section{Radhika P Ramachandran ${ }^{1 *}$ and Laxmi U Yelledahalli²}

${ }^{1}$ Department of Biotechnology, Faculty of Engineering and Technology, SRM University

${ }^{2}$ Department of Biotechnology, East west college science and Technology, Bangalore

\begin{abstract}
During the past several years there has been a vivid research in the field of stem cell. This article explores the recent advances in the field of stem cell research and the ethical issues involved in it. By definition, stem cells are undifferentiated cell characterized by the ability to renew themselves and differentiating into a diverse range of specialized cell types. Even though stem cells have potential to treat various diseases, their application is controversial. Due to these ethical concerns scientists are trying to find new ways of obtaining stem cells that behave like embryonic stem cells without harming a blastocyst. Moreover, there is a growing body of evidence showing that administration of stem cells leads to the successful regeneration of tissues or organ.
\end{abstract}

Keywords: Mesenchymal stem cells; Regenerative medicine; Osteoblast; Chondroblast; Adipoblast

\section{Introduction}

Stem cells are autologous cells having a long-term self-renewal ability that regenerates and differentiates into various cells, tissues, organs, and systems in the human body [1,2]. Stem cell therapy is an amazing modern medical advancement that goes straight to the source of the problem and treats various disorders like muscular dystrophy, Alzheimer's disease, Atherosclerosis, Diabetes, Inflammatory Bowel Disease, Parkinson's disease, Rheumatoid Arthritis, acute lung injury and many others [3-5]. Adult stem cells can rapidly proliferate to regenerate the specialized tissues [6,7]. Mesenchymal stem cell (MSC) is a type of stem cell has entered the scene as a developing therapy. Recently, mesenchymal stem cells have been found in skin, liver and other tissues [7,8]. Mesenchymal stem cells are the conventional terms used to describe the collection of poorly defined multipotent mesenchymal stromal cells, which can differentiate into a variety of cell types, including osteoblast ,chondroblast, myoblast and adipoblast (Figure 1) [5,9,10].

MSCs have the capacity to differentiate into several cell types and it can be isolated from embryonic or adult tissues such as bone marrow and adipose tissue $[11,12]$. MSCs found to have anti-inflammatory effects and treat various painful states such as degenerative disc disease, osteoarthritis, cartilage regeneration, multiple sclerosis [1316]. Stem cells are unique from other cell types by two important characteristics. First, they are undifferentiated cells capable of renewing themselves through cell division, even after long periods of inactivity. Second, under certain experimental and physiologic conditions, they can be induced to become tissue- or organ-specific cells with special functions. Researchers primarily worked with two kinds of stem cells from animals and humans: embryonic stem cells and adult stem cells (somatic stem cells).

Embryonic stem cell and umbilical cord blood also show promise in the field of cardiac regeneration [17]. The uses of adult stem cells are morally ethical, but it is unethical to use embryonic stem cells since it involves the destruction of the embryos. The embryonic stem cells can be taken for research with the informed consent from the donor[18]. The donor will be fully informed regarding the reasonably foreseeable impact of the research on the fetus or neonate $[19,20]$. All the ethical problems related to this field of research should be reviewed by the institutional review board (IRB) [21,22].Organ regeneration is also possible through organ-specific and tissue-specific stem cells [23]. Hematopoietic stem cells were believed to restore blood cells. It has been discovered recently that using cell lineage tracking, stem cells from one organ can be used to form cells of another organ. MSCs shown to have the ability to form neural cells both in vitro and in vivo, although the exact molecular mechanisms underlying these apparent transdifferentiation events are not known [24]. Neural stem cells migrate toward sites of damaged CNS tissue and it differentiates into special cell types of CNS and repair damage tissue [25].

Stem cell therapy has been shown successful for the treatment of leukemia [26]. One way is to get rid of all the abnormal leukocytes in the patient, allowing healthy ones to grow in their place it can be done by chemotherapy the other way is to carry out the bone marrow transplant. In bone marrow transplantion, the patient's bone marrow stem cells are replaced with those from a healthy, matching donor. To do this, first of all patient's existing bone marrow cells and abnormal leukocytes are first killed using a combination of chemotherapy and radiation. Next, donor bone marrow containing healthy stem cells should be introduced into the patient's bloodstream. If the transplantion is successful, the stem cells will migrate into the patient's bone marrow and begin producing healthy leukocytes to replace the abnormal cells [27].

\section{History of Stem Cell Research}

Stem cells have an interesting history that traces from mid of 1800 to the date, and it remains the most controversial topic of research even today [2In 1878 attempts were made to fertilize mammalian eggs outside the body.

*Corresponding author: Radhika. P. Ramachandran, Department of Biotechnology, Faculty of Engineering and Technology, SRM University, Chennai, India, E-mail: radhika.mtechbio@gmail.com

Received September 06, 2011; Accepted October 31, 2011; Published November 02, 2011

Citation: Ramachandran RP, Yelledahalli LU (2011) Exploring the Recent Advances in Stem Cell Research. J Stem Cell Res Ther 1:113. doi:10.4172/21577633.1000113

Copyright: () 2011 Ramachandran RP, et al. This is an open-access article distributed under the terms of the Creative Commons Attribution License, which permits unrestricted use, distribution, and reproduction in any medium, provided the original author and source are credited. 
Citation: Ramachandran RP, Yelledahalli LU (2011) Exploring the Recent Advances in Stem Cell Research. J Stem Cell Res Ther 1:113. doi:10.4172/2157-7633.1000113

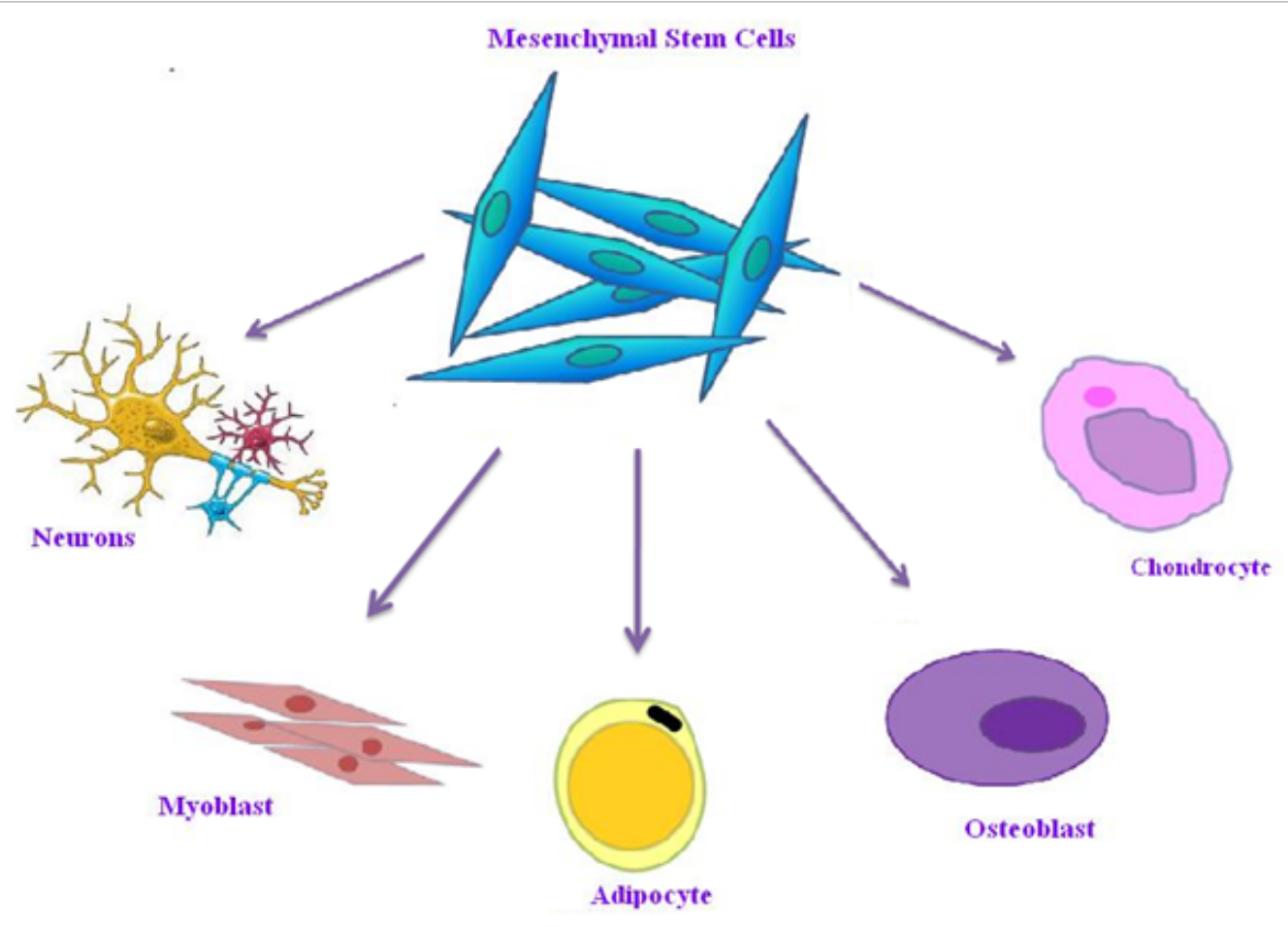

Figure 1: Mesenchymal Stem cell Differentiation.

- In 1952 Briggs and King cloned tadpoles.

- In 1954 John Enders received a Nobel Prize in Medicine for growing polio virus in human embryonic kidney cells.

- In 1958 Jean Dausset identified the first human histocompatibility antigens.

- In 1959 First animals made by in-vitro fertilization (IVF).

- In 1960 Teratocarcinomas determined to originate from embryonic germ cells in mice. Embryonal carcoinoma cells (EC) identified as a kind of stem cell.

- In 1960's that physician knew enough about HLA compatibility to perform transplants between siblings who were not identical twins.

- In 1968 the first human egg is fertilized in vitro.

- In 1968 the first bone marrow transplant (adult stem cells) was successfully used in treatment of SCID.

- In 1970s EC cells injected into mouse blastocysts make chimeric mice. Cultured cells are explored as models of embryonic development in mice.

- In 1973 a team of physicians performed the first unrelated bone marrow transplant.

- In 1973 moratorium on government financing for human embryo research.

- In 1978 the first IVF baby is born.

- In 1981 Mouse Embroyonic stem cells are derived from the inner cell mass of blastocysts.
- In 1984-88 Embryonal Carcinoma (EC) cells are developed. When exposed to retinoic acid these cells differentiate into neuron-like cells and other cell types.

- In 1984 Congress passed the National Organ Transplant Act.

- In 1989 A clonal line of human embryonic carcinoma cells that have limited replicative and differentiative capacity is derived that yields tissues from all three primary germ layers. They have limited replicative and differentiative capacity.

- In 1994 Human blastocysts are generated and the inner cell mass is maintained in culture. ES like cells form in the center and retain stem cell like morphology.

- In 1995-96 Non-human primate ES cells are maintained in vitro from the inner cell mass of monkeys. These cells are pluripotent and differentiate normally into all three primary germ layers.

- In 1998 Embryonic stem cells from the inner cell mass of normal human blastocysts are cultured and maintained normally for many passages. EG cells are also derived and grown in vivo.

- In 1998, James Thompson (University of Wisconsin - Madison) isolated cells from the inner cell mass of early embryos, and developed the first embryonic stem cell lines.

- In 2000, President Bill Clinton allotted funding of research on cells derived from aborted human fetuses.

- In 2000 Scientists derive human embryonic stem cells from the inner cell mass of blastocysts.

- In 2001 Human embryonic stem cell lines are shared and new lines are derived, more research groups are focusing attention 
on the differentiation of cells in vitro.

- In 2001 President George W. Bush announced his decision to allow Federal funding of research only on existing human embryonic stem cell lines created prior to his announcement.

- In 2004 both houses of Congress have asked President George W. Bush to review his policy on embryonic stem cell research.

- In 2004 First human cloned blastocyst created - later proved to be fraudulent.

- In 2004 election, California had a Stem Cell Research Funding authorization initiative on the ballot that won by a $60 \%$ to $40 \%$ margin. It established the "California Institute for Regenerative Medicine" to regulate stem cell research and research facilities.

- In 2004 to 2005, when Hwang Woo-Suk, a Korean researcher, claimed to have produced human embryonic stem cell lines from unfertilised human eggs.

- In early 2007, researchers led by Dr. Anthony Atala claimed that a new type of stem cell had been isolated in amniotic fluid.

- In 2005 National Academies Releases "Guidelines for Human Embryonic Stem Cell Research".

- In December 2006: ISSCR Release Guidelines for stem cell research.

- In 2008 NAS Release New Guidelines for stem cell research.

- In 2008 ISSCR Releases Guidelines for Clinical Translation.

- In 2010 Clinical Trial of Human Embryonic Stem Cell-Based Therapy was initiated.

- In 2011 Researchers found that stem cell infusion generates $30 \%$ more new cardiac Cells.

- In 2011 researchers uncovered the mechanism governing the Pluripotent Stem Cell Metabolism.

- In 2011 Israeli scientist Inbar Friedrich Ben-Nun led a team which produced the first stem cells from endangered species, a breakthrough that could save animals in danger of extinction.

\section{Different Sources of Stem cells}

Stem cells can be taken from variety of sources like bone marrow, cardiac cells, liver, skin, umbilical cord blood, muscle, peripheral blood the inner cell mass of blastocysts etc. [34,35] (Figure 2).

\section{Ethical Consideration of Stem Cell Research}

Most of the ethical issues surrounding stem cell research involve embryonic stem cells because they are derived from fertilized embryos, which are subsequently destroyed in the research process. The embryos used for research, however, are not derived from eggs fertilized in a woman's body; rather they are fertilized in vitro in a fertilization clinic and donated for research purposes with informed consent of the donor [36-38] or human fetal tissue following elective abortion [39,40]. An adult stem cell, on the other hand, is an undifferentiated cell found in organ or tissue that has the ability to renew itself. By nature, adult stem cells are not as controversial because they can be derived from an individual who may require the therapy by extracting them from the bone marrow or skin.

NIH guidelines for stem cell therapy say that, embryonic stem cells can be derived from stem cells of an embryo only when the embryo is no longer needed for reproductive purposes. A written informed consent should be obtained from the donor, indicating the willingness of the donor to allow use of the embryo for human embryonic stem cell related research and therapy [41]. No commercialization will be allowed. Guidelines have included even medical benefit of donation that in the future such cells might be used for the medical benefit of the person donating them[36].National Academy of Sciences(NAS) has given specific guidelines for the conduct of research on Human embryonic stem cells(hESC) [42].

\section{Is Stem Cell Therapy The Future of Regenerative Medicine?}

Regenerative Medicine deals with replacement or regeneration of human cells, tissues or organs, to restore or establish the normal function. In regenerative medicine, the uses of stem cells are therapeutically valuable for the regeneration of diseased tissues and organs [43]. Researchers suggest that adult stem cells are crucial for all physiological tissue renewal and regeneration after injury or disease [36]. Another theory says that the bone marrow cell injected secretes cytokines that promote angiogenesis and consequently, osteogenesis is induced on the necrotic area by increasing angiogenesis, suggesting that stem cells can heal necrotic tissue [44]. Some study suggests that MSC showed a fibroblast-like morphology and can be differentiated in vitro into osteogenic lineages [45]. Adult human stem cells have also been isolated or identified from human kidney, breast, pancreas, mesenchyme, liver and prostate [46].These stem cells can be used for regeneration treatment $[47,48]$.

Researchers proved that distal airway stem cells (DASCs), a specific type of stem cells in the lungs, are involved in forming new alveoli to replace and repair damaged lung tissue, providing a firm foundation for understanding lung regeneration [49,50]. Italian and Spanish scientists have provided the evidence to show that meninges, the membrane which envelops the central nervous system, is a potential source of selfrenewing stem cells to treat spinal cord injuries [51]. Several clinical trials utilizing bone marrow derived progenitor cells to repair damaged myocardium have been completed with positive result[17].According to the researcher at the western university in Australia, human breast milk has the potential to treat diseases like Parkinson's and diabetes[52] (Figure 3). High concentrations of stem cells are required for the tissue repair technology, such as reconstructed skin. For this purpose, stem cells can be cultured in media [53]. Stem cell therapy holds a great promise for the repair of injured organs, including kidney [54].

Stem cell populations with high aldehyde dehydrogenase (ALDH) enzymatic activity (ALDHbr cells) from cord blood and bone marrow can be used as a therapy to treat cardiovascular diseases [55,56]. Adipose tissues are valuable sources of adipose stem cells which can be used as a pharmacological tool for the treatment of various degenerative diseases.[57-59]. Cumulative evidence demonstrates that bone marrow stem cells contribute to cardiac repair in vivo and prevent ventricular remodeling and alleviate cardiac symptoms [60,61]. Stem cells have 
Citation: Ramachandran RP, Yelledahalli LU (2011) Exploring the Recent Advances in Stem Cell Research. J Stem Cell Res Ther 1:113. doi:10.4172/2157-7633.1000113

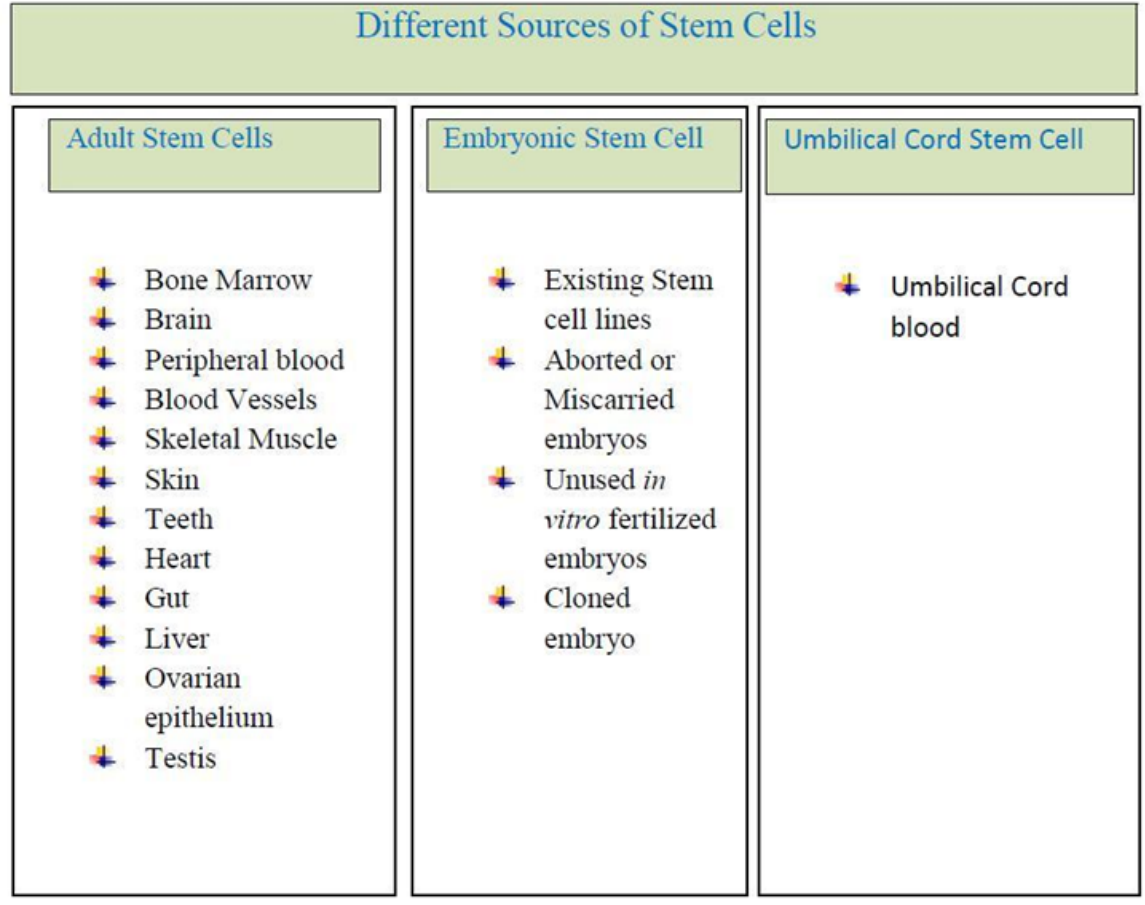

Figure 2: Different Sources of Stem cells.

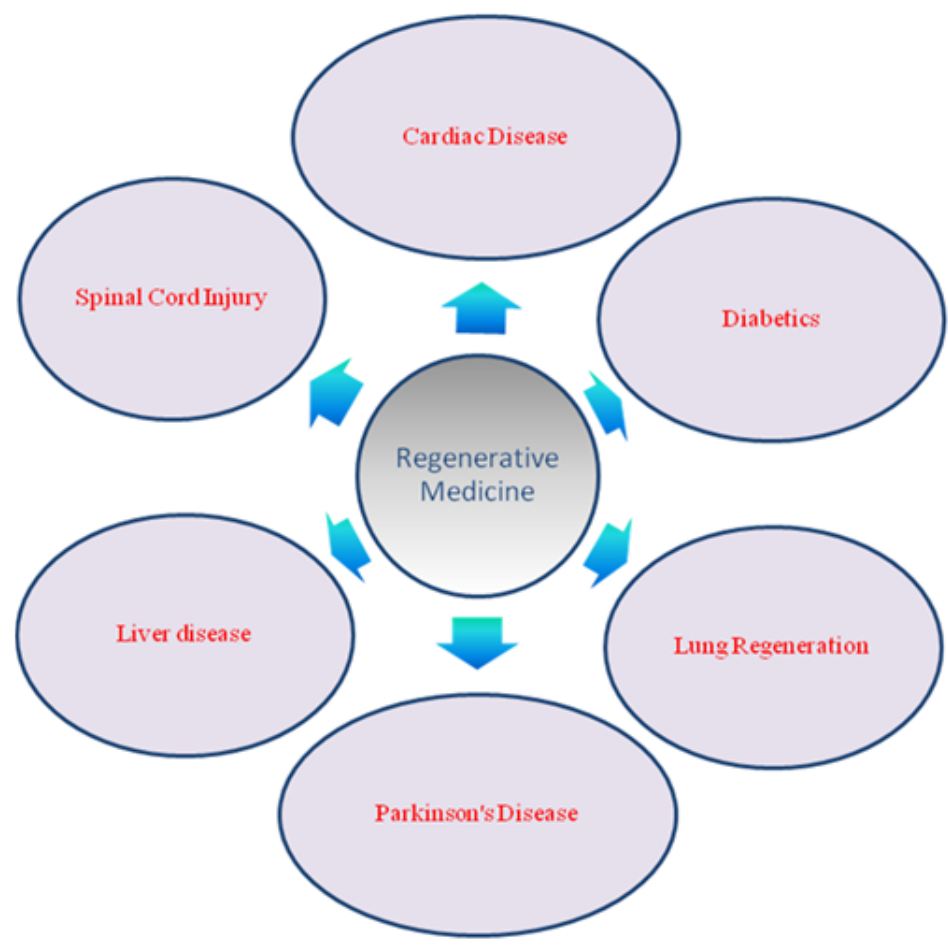

Figure 3: Application of Stem cells.

been intensively investigated as a potential source of liver stem cells and as a means to regenerate the cirrhotic liver $[62,63]$.

\section{Conclusion}

In conclusion, the controversy over human embryonic stem cell research still remains unsolved, but the potential of stem cell to treat the disease is most exciting. Unlocking stem cell potential still require much more continued research and one day it is going to be a common 
Citation: Ramachandran RP, Yelledahalli LU (2011) Exploring the Recent Advances in Stem Cell Research. J Stem Cell Res Ther 1:113. doi:10.4172/2157-7633.1000113

Page 5 of 6

treatment for degenerative diseases. The future of stem cell research is indeed promising, yet scientific challenges must be overcome one-byone.

\section{References}

1. Shrihari TG (2011) Cancer Stem Cells - Therapeutic Boon! J Cancer Sci Ther 3: 197-200.

2. Cruz M, Siden A, Tasat DR, Yakisich JS (2010) Are all Glioma Cells Cancer Stem Cells? J Cancer Sci Ther 2: 100-106.

3. Meregalli M, Farini A, Torrente $Y$ (2011) Mesenchymal Stem Cells as Muscle Reservoir. J Stem Cell Res Ther 2: 105.

4. Elsheikh E, Genead R, Danielsson C, Wärdell E, Andersson A, et al. (2011) Isolation and Characterization of the SSEA-1+ Progenitor Cells from the Human Embryonic Heart. J Cytol Histol 2: 122.

5. Letourneau PA, Menge TD, Wataha KA, Wade CE, Cox CS Jr, et al. (2011) Human Bone Marrow Derived Mesenchymal Stem Cells Regulate LeukocyteEndothelial Interactions and Activation of Transcription Factor NF Kappa B. J Tissue Sci Eng S3: 001.

6. Ponnusamy MP (2011) Stem Cell Research and Cancer Stem Cells. J Tissue Sci Eng 2: 104e.

7. Silvani G, Galli D, Benedetti L, Ceccarelli G, Crosetto N, et al. (2011) Peculiar Characteristics of Human Mesenchymal Stem Cell Clones Suitable as Tissue Engineering Models. J Tissue Sci Eng 2: 106.

8. Minguell JJ, Pereira A, Bartholomew P and Lasala GP (2011) The Intratheca Infusion of Mesenchymal Stem Cells into Healthy Rabbits is Safe and Devoid of Neurological or Clinical Complications. J Stem Cell Res Ther 2: 104

9. Canelles M (2011) The Universality of Asymmetric Division. J Stem Cell Res Ther 1: e103.

10. Mittal R (2011) Mesenchymal Stem Cells: The New Players in the Pathogenesis of Tuberculosis. J Microbial Biochem Technol 3: ii-0.

11. Ghodsizad A, Voelkel T, Moebius JM, Gregoric I, Bordel V, et al. (2010) Biological Similarities Between Mesenchymal Stem Cells (Mscs) and Fibroblasts. J Cytol Histol 1: 101.

12. Razmkhah M, Jaberipour M, Ghaderi A (2011) Chemokines and Chemokine Receptors Expression in the Adipose Derived Stem Cells (ASCs), Breast Tissues and in Peripheral Blood of Patients with Breast Cancer. J Carcinogene Mutagene 2: 120

13. Waterman Ruth S, Betancourt AM (2011) Treating Chronic Pain with Mesenchymal Stem Cells: A Therapeutic Approach Worthy of Continued Investigation. J Stem Cell Res Ther S2: 001

14. Pei M, He F, Wei L (2010) Three-Dimensional Cell Expansion Substrate For Cartilage Tissue Engineering And Regeneration: A Comparison In Decellularized Matrix Deposited By Synovium-Derived Stem Cells And Chondrocytes. J Tissue Sci Eng 2: 104.

15. Novik AA, Kuznetsov AN, Melnichenko VY, Fedorenko DA, lonova TI, et al. (2011) Non-myeloablative Autologous Haematopoietic Stem Cell Transplantation with Consolidation Therapy using Mitoxantrone as a Treatment Option in Multiple Sclerosis Patients. J Stem Cell Res Ther 1: 102.

16. Sollazzo V, Palmieri A, Girardi A, Farinella F, Carinci F (2011) Trabecular Titanium Induces Osteoblastic Bone Marrow Stem Cells Differentiation. J Biotechnol Biomaterial 1: 102

17. Duran JM, George JC (2011) A Review of the Basis of Autologous Stem Cell Therapy for Coronary Artery Disease. J Clinic Experiment Cardiol 2: 130.

18. Jamil K, Kumar K, Fatima SH, Rabbani S, Kumar R, et al. (2009) Clinical Studies on Hormonal Status in Breast Cancer and its Impact on Quality of Life (QOL). J Cancer Sci Ther 1: 083-089.

19. Allesee L, Gallagher CM (2011) Pregnancy and Protection: the Ethics of Limiting a Pregnant Woman's Participation in Clinical Trials. J Clinic Res Bioeth 2: 108.

20. Master Z, Ries NM, Caulfield T (2011) Balancing Efficiency and the Protection of Research Participants: Canadian Allergy/Asthma Researchers' Perspectives on the Ethics Review of Multi-Site Health Research. J Clinic Res Bioeth 2 104 e.

21. Smalheiser NR (2011) Sometimes Non-IRB Approved Research Deserves A Second Look. J Clinic Res Bioeth 2: 104.

22. Mzayek F, Resnik D (2010) International Biomedical Research and Research Ethics Training in Developing Countries. J Clinic Res Bioeth 1: 103.

23. Danobeitia JS (2011) Organ Transplantation in the open-access era. J Transplant Technol Res 1: 104e.

24. Jackson L, Jones DR, Scotting P, Sottile V (2007) Adult mesenchymal stem cells: Differentiation potential and therapeutic applications. J Postgrad Med 53 : 121-127.

25. Yu L, Ma J, Ma R, Zhang Y, Zhang X, et al. (2011) Repair of Excitotoxic Neuronal Damage Mediated by Neural Stem Cell Lysates in Adult Mice. J Cell Sci Ther 2: 109

26. Ziai J, Torres R, Tormey CA (2010) Chronic Neutrophilic Leukemia: A Rare and Difficult Diagnosis of Exclusion. J Blood Disord Transfus 1: 102.

27. http://learn.genetics.utah.edu/content/tech/stemcells/sctoday/

28. http://biomed.brown.edu/Courses/BI108/BI108_2002_Groups/pancstems/ stemcell/stemcell_history.htm

29. http://www.explorestemcells.co.uk/historystemcellresearch.htm

30. Bajotto AP, Goldim JR (2011) Case-Report: Autonomy and Self Determination of an Elderly Population in South Brazil. J Clinic Res Bioeth 2: 109.

31. http://stemcellhistory.com/stem-cell-research-timeline/

32. http://www.stemcellresearchnews.com/Headlines_Page.htm

33. http://www.stockmarketsreview.com/news/199140/

34. http://www.haaretz.com/print-edition/news/israeli-scientist-leads breakthrough-stem-cell-research-on-endangered-species-1.382754

35. Gottlieb H, Klausen TW, Boegsted M, Olsen BS, Lausten GS, et al. (2011) A Clinical Study of Circulating Cellular and Humoral Biomarkers Involved in Bone Regeneration Following Traumatic Lesions. J Stem Cell Res Ther 1: 108.

36. Porrata LF, Inwards DJ, Ansell SM, Micallef IN, Johnston PB, et al. (2011) Day 15 Peripheral Blood Lymphocyte/monocyte Ratio Post-autologous Periphera Hematopoietic Stem Cell Transplantation and Survival in Diffuse Large B-cell Lymphoma. J Stem Cell Res Ther 1: 103.

37. http://stemcells.nih.gov/policy/2009guidelines.htm

38. Karkar A (2011) Towards Efficient, Broad and Accessible Electronic Scientific Publication. J Transplant Technol Res 1: 102e.

39. Triolo V, Argo A, Zerbo S, Procaccianti P (2010) Legislation and Comparison with Some International Laws. J Forensic Res 1: 108.

40. Gainotti S, Petrini C (2011) Therapeutic Misconception in Early Phase Trials: Relation is the Cure. J Clinic Res Bioeth 2:103e.

41. Freeman JM (2010) Reflections on Clinical Ethics. J Clinic Res Bioeth 1:102.

42. Gallagher CM, Holmes RF (2011) Retrospective Review of Medical Futility and Ethics Consultations at MD Anderson Cancer Center. J Clinic Res Bioeth 2: 115

43. Rameshwar P (2011) Post-identification of Cancer Stem Cell: Ethical and Scientific Dilemmas in Therapeutic Development? J Stem Cell Res Ther 1 e101.

44. Patel R, Lomax G (2011) Use of hESC Lines by CIRM Grantees: The Value of Embryonic Stem Cell Research Oversight (ESCRO) Committees. J Stem Cell Res Ther 1: 107

45. Mansilla E, Díaz Aquino V, Roque G, Tau JM, Maceira A, et al. (2011) Building Small Spheroids/Regenerative Units for Hair Loss Treatment: Just Imitating Nature in an Industrialized Manner. Hair : Therap Transplantat 1: e101.

46. Hwang J, Lee S, Park H, Kim M (2011) Autologous Bone Marrow Transplantation 
Citation: Ramachandran RP, Yelledahalli LU (2011) Exploring the Recent Advances in Stem Cell Research. J Stem Cell Res Ther 1:113. doi:10.4172/2157-7633.1000113

in Osteonecrosis of the Femoral Head. J Tissue Sci Eng 2: 103.

47. Warstat K, Felka T, Mittag F, Kluba T, Rolauffs B, et al. (2011) The TGF- $\beta 1$ Induced Expression of Matrix Metalloproteinases in Mesenchymal Stromal Cells is Influenced by Type of Substrate. J Tissue Sci Eng 2: 108.

48. Shah D, Nandakumar S, Jaishankar GB, Chilakala S, Wang K, et al. (2011) PreTerm Exposure Patterns in Neonatal Intensive Care Unit Alters Immunological Outcome in Neonates. J Aller Ther 2: 106.

49. Irioda AC, Zocche L, Souza CMCO, Ferreira RJ, Aliprandini E, et al. (2011) Pap Test as the First Step in Screening Genetic Stability in Cell-Based Therapy. J Stem Cell Res Ther 1: 106.

50. Minuth WW, Denk L, Glashauser A (2010) Promoting and Harmful Effects of Steroid Hormones on Renal Stem/Progenitor Cell Development. J Tissue Sci Eng 1: 101.

51. Agency for Science, Technology and Research (A*STA. "Research Breakthrough That Paves The Way For Novel Therapies For Respiratory Diseases." Medical News Today. MediLexicon, Intl., 31 Oct. 2011. Web.

52. Ratajczak MZ, Kim CH (2011) Bioactive Sphingolipids and Complement Cascade as New Emerging Regulators of Stem Cell Mobilization and Homing. J Stem Cell Res Ther 1: e102.

53. Decimo I, Bifari F, Rodriguez F, Malpeli G, Dolci S, et al. (2011) Nestin- and DCX-positive cells reside in adult spinal cord meninges and participate to injury-induced parenchymal reaction. Stem Cells, 29 :2062-2076

54. http://www.news.uwa.edu.au/201110174047/awards-and-prizes/breastmilknatural-stem-cell-therapy

55. Xavier Batista FR, Rehder J, Puzzi MB (2010) Evaluation of Culture Medium for
Human Keratinocytes. J Stem Cell Res Ther 1: 101.

56. Abdel Aziz MT, Wassef MA, Rashed LA, Mhfouz S, Omar N, et al. (2011) Mesenchymal Stem Cells Therapy in Acute Renal Failure: Possible Role of Hepatocyte Growth Factor. J Stem Cell Res Ther 1: 109.

57. Kablan A, Saunders RA, Szkudlarek-Mikho M, Chin JB, Bosio RM, et al. (2010) Prieurianin Causes Weight Loss in Diet-Induced Obese Mice and Inhibits Adipogenesis in Cultured Preadipocytes. J Diabetes Metab 1: 101.

58. Hwang WS, Ryu YJ, Park JH, Park ES, Lee EG, et al. (2004) Evidence of a Pluripotent Human Embryonic Stem Cell Line Derived from a Cloned Blastocyst. Science 303: 1669-1674.

59. Glashauser A, Denk L, Minuth WW (2011) Polyester Fleeces used as an Artificial Interstitium Influence the Spatial Growth of Regenerating Tubules. J Tissue Sci Eng 2: 105.

60. Valarmathi MT, Fuseler JW (2011) Mammalian Cardiac Muscle Regeneration: Structural and Functional Modulation of Adult Marrow Stromal Stem Cells. Anatom Physiol 1: e102.

61. Lionetti V (2011) How Resident Stem Cells Communicate with Cardiac Cells in Beating Heart? J Stem Cell Res Ther 1: e104.

62. Jovic D, Haque A, Hexig B, Nagaoka M, Akaike T (2011) Control of Singular Cell Cycle Synchronization of Mouse ES Cells for Hepatocyte Differentiation on E-Cadherin Substratum. J Biotechnol Biomaterial 1: 113.

63. Nakazawa K, Shinmura Y, Higuchi A, Sakai Y (2011) Effects of Culture Conditions on a Micropatterned Co-culture of Rat Hepatocytes with 3T3 cells. J Bioprocess Biotechniq S3: 002. 